\title{
PENGEMBANGAN TOPIK BENCANA ALAM DALAM PEMBELAJARAN IPS UNTUK MENINGKATKAN KECERDASAN EKOLOGIS SISWA DALAM MERAWAT LINGKUNGAN SEKOLAH
}

\author{
Rizky Satria, SMP Semi Palar Bandung \\ email: rizky.std2034@gmail.com
}

\begin{abstract}
Abstrak
Saat ini kondisi kerusakan alam di Indonesia sudah semakin memprihatinkan. Karena tidak banyak orang yang memedulikannya, kerusakan alam tersebut mencapai titik terparah hingga menyebabkan berbagai fenomena bencana. Siswa sekolah sebagai generasi muda diharapkan dapat ikut berpartisipasi dalam memperbaiki permasalahan tersebut, namun kondisi di lapangan menunjukkan bahwa siswa belum memiliki kecerdasan ekologis yang memadai dalam merawat lingkungan. Tujuan penelitian ini adalah untuk meningkatkan kecerdasan ekologis siswa di Kelas 7 SMP Semi Palar Bandung. Metode penelitian menggunakan PTK dengan model spiral multi siklus dari Kemmis dan Taggart. Dari hasil analisis pencapaian level dan kompetensi kesadaran ekologis, menunjukkan bahwa melalui pengembangan topik materi bencana alam dalam pembelajaran IPS, kecerdasan ekologis siswa dalam merawat lingkungan dapat meningkat dengan optimal. Kesimpulan penelitian ini mengajak para guru agar dapat mengembangkan topik dan metode belajar yang beragam dalam pembelajaran IPS untuk meningkatkan kesadaran ekologis siswa sesuai dengan kebutuhan dan kondisi kelas.
\end{abstract}

Kata Kunci: Bencana Alam, Pembelajaran IPS, Kecerdasan Ekologis.

\section{Pendahuluan}

Permasalahan kerusakan lingkungan alam di Indonesia menjadi wacana yang semakin penting untuk diperhatikan. Menurut laporan dari Forest Watch Indonesia (FWI) dan Global Forest Watch (GFW), menunjukkan bahwa kondisi hutan lebat di Indonesia saat ini hanya tersisa sekitar 98 juta hektar, dan paling sedikit setengahnya diyakini sudah mengalami degradasi akibat kegiatan manusia. Kondisi ini semakin diperparah oleh laju deforestisasi yang semakin meningkat karena sejak tahun 1996 angka pengurangan hutan mencapai hingga sekitar 2 juta ha per tahun. (Holmes, dalam FWI/GFW, 2001). Dalam hal ini, Pranadji (2005) mencatat bahwa kerusakan lingkungan yang sangat serius di Indonesia disebabkan oleh perkembangan di era modernisasi yang tidak mendukung kepada pembangunan berkelanjutan (sustainable development) yang seharusnya berporos pada aspek keadilan dan penguatan sosiobudaya bangsa.

Permasalahan lingkungan yang tidak terselesaikan dapat menyebabkan beragam kerugian dari skala kecil hingga besar. Dalam Tinjauan Lingkungan Hidup yang dirilis oleh Wahana Lingkungan Hidup (WALHI, 2014), menunjukkan bahwa kerusakan lingkungan di Indonesia telah menyebabkan terjadinya bencana alam atau bencana ekologis seperti banjir, longsor, kabut asap, dan sebagainya. Dalam paparan 
tersebut, WALHI mencatat jika dibandingkan dengan wilayah-wilayah lain yang ada di Indonesia, wilayah Jawa tercatat sebagai daerah dengan tingkat bencana ekologis tertinggi di mana tingkat korban jiwa terbanyak berada di daerah Jawa Barat.

Siswa sekolah sebagai generasi muda yang potensial untuk menciptakan perbaikan lingkungan di masa depan diharapkan dapat ikut berpartisipasi untuk menjaga kelestarian lingkungan dalam upaya pencegahan bencana di lingkungan sekitarnya. Namun, dari apa yang peneliti amati di sekolah, pada umumnya sikap kepedulian siswa terhadap lingkungan belum terbangun dengan baik. Kondisi ini terlihat dari abainya perhatian mereka terhadap keberadaan sampah dan tanaman atau pepohonan yang berada di sekitar area sekolah. Karena hal tersebut, peran untuk merawat lingkungan sekolah akhirnya hanya diserahkan -dan seakan menjadi tanggung jawab mutlak- penjaga sekolah, tukang kebun, dan tenaga kebersihan sekolah saja. Oleh karena itu, rendahnya kesadaran dan kepedulian siswa terhadap lingkungan merupakan permasalahan yang mesti dipecahkan.

Untuk menumbuhkan kesadaran dan kepedulian siswa terhadap lingkungan, hal yang dapat dilakukan oleh guru adalah mengembangkan pendekatan ekopedagogi. Hal ini selaras dengan penjelasan dari Antunes \& Gadotti (2011) sebagai berikut:

Pendidikan terhubung dengan ruang dan waktu di mana hubungan antara manusia dan lingkungan benar-benar terjadi. Hal tersebut terutama terjadi pada tingkat emosional, lebih banyak dari pada tingkat kesadaran. Dengan demikian, hal tersebut ada dalam bawah sadar kita; kita tidak menyadarinya dan sering kali kita tidak tahu bagaimana hal itu terjadi. Jadi, eco-education diperlukan untuk membawa mereka (siswa) ke tingkat sadar. Tentu, ecoeducation membutuhkan pedagogi. Oleh karenanya, saat ini kita perlu ecoeducation dan eco-pedagogy.

Selanjutnya, Supriatna (2016) menjelaskan bahwa ekopedagogi merupakan sebuah gerakan akademik untuk menyelamatkan bumi dan semua makhluk hidup yang ada di dalamnya demi perkembangan yang berkesinambungan (education for sustainable development). Lebih jauh, Grigorov dan Fleuri (dalam Supriatna, 2016) menjelaskan bahwa "ekopedagogi adalah gerakan yang berangkat dari masalah-masalah kehidupan yang nyata dan didasari oleh perspektif kehidupan".

Dalam penerapannya di kelas, pendekatan ekopedagogi dapat mendukung upaya untuk meningkatkan kecerdasan ekologis (ecoliteracy) siswa. Menurut David Orr (Blake, 2015) kecerdasan ekologis adalah "pemahaman tentang bagaimana bumi berfungsi: ekosistem tergantung pada satu sama lain, dan campur tangan di antaranya akan berdampak pada lingkungan dalam berbagai cara" (ecological literacy is an understanding of how the earth functions: ecosystems are dependent on each other, and human interference in any of them impacts the environment in multiple ways). Oleh karena itu, menurut Supriatna (2016), "seseorang yang cerdas secara ekologis adalah orang yang memahami bahwa setiap perilaku dan tindakannya tidak hanya berdampak pada dirinya dan orang lain, melainkan juga pada lingkungan alam tempat dia tinggal".

Pendekatan ekopedagogi sangat mungkin dikembangkan dalam pembelajaran IPS dalam kurikulum 2013 karena keselarasannya dengan keempat Kompetensi Inti dan beberapa Kompetensi Dasar untuk setiap kelas seperti poin 1.3 (Manusia dan 
lingkungan sebagai ciptaan Tuhan YME), 2.3 (Kepedulian lingkungan), $3.1 \& 4.1$ (Keberlanjutan kehidupan manusia), serta 3.4 \& 4.4 (Dinamika interaksi manusia dengan lingkungan alam).

Dalam penelitian ini, untuk mencapai sasaran meningkatkan kecerdasan ekologis siswa, guru sebagai peneliti mencoba mengembangkan topik tentang sebuah peristiwa bencana alam yang terjadi di wilayah Indonesia dalam satu rangkaian kegiatan dengan mengolah beragam metode belajar aktif (active learning) seperti inkuiri, diskusi kelompok/kelas, serta praktek lapangan. Untuk mengintegrasikan kegiatan dalam sebuh alur pembelajaran, peneliti menggunakan rancangan design thinking yang dikembangkan oleh tim kurikulum SMP Semi Palar Bandung (www.semipalar.sch.id), sebagai berikut:

\section{Gambar 1}

\section{Design Thinking Alur Pembelajaran Topik Bencana Alam dalam Pembelajaran IPS}

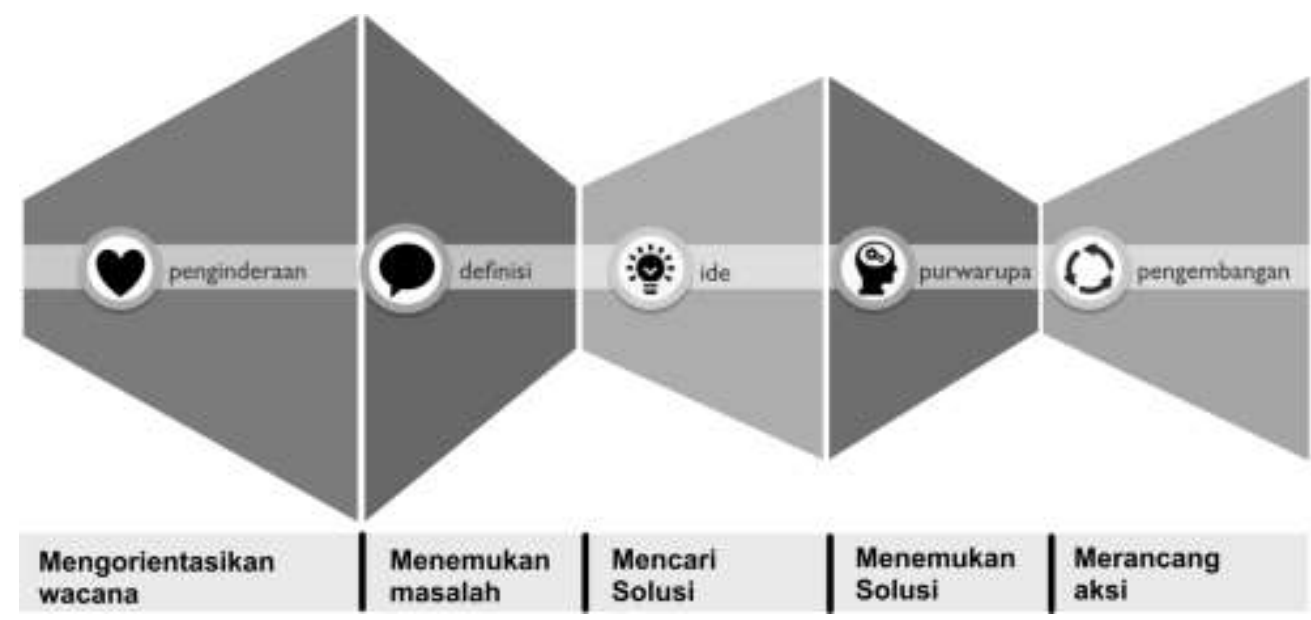

Tabel 1

Langkah Kegiatan \& Metode Pengembangan Topik Bencana Alam dalam Pembelajaran IPS

\begin{tabular}{|l|l|l|}
\hline Langkah & Kegiatan & Metode \\
\hline 1 & Orientasi wacana & Diskusi Kelas \\
\hline 2 & Identifikasi masalah & Inkuiri, Diskusi Kelompok, dan \\
\hline 3 & Perumusan solusi & Diskusi Kelas. \\
\hline 4 & Perancangan aksi & Praktek lapangan \\
\hline
\end{tabular}

Dalam merumuskan sasaran belajar untuk meningkatkan kecerdasan ekologis dalam merawat lingkungan sekolah, peneliti mengembangkan kerangka kesadaran ekologis (Frameworks for Ecoliteracy) dari "Empat Set Kompetensi untuk Kecerdasan Ekologis" dari Capra dan "Empat tingkat Kesadaran Ekologis" dari Cutter-Mackenzie and Smith yang dikutip dari McBride et al. (2013), sebagai berikut: 


\section{Tabel 2}

\section{Set Kompetensi Kesadaran Ekologis dari Capra dan 4 Level Kesadaran Ekologis dari Cutter-Mackenzie and Smith (McBride et al., 2013)}

\begin{tabular}{|l|l|l|}
\hline 1 & $\begin{array}{l}\text { Capra, Center for Ecoliteracy | Four Sets } \\
\text { of Competencies for Ecoliteracy (2013) }\end{array}$ & $\begin{array}{l}\text { Cutter-Mackenzie and Smith | Four Levels } \\
\text { of Ecoliteracy (2003) }\end{array}$ \\
$\begin{array}{l}\text { Head/cognitive-approach issues from a } \\
\text { systems perspective, understand } \\
\text { fundamental ecological principles (networks, } \\
\text { nested systems, cycles, flows, development, } \\
\text { dynamic balance), think critically, assess } \\
\text { impacts and ethical effects of human actions, } \\
\text { envision long-term consequences of } \\
\text { decisions; } \\
\text { misconceptions about environmental issues; }\end{array}$ & $\begin{array}{l}\text { Heart/emotional-feel concern, empathy, } \\
\text { and respect for other people and living } \\
\text { things, appreciate multiple perspectives, } \\
\text { commit to equity and justice for all people; }\end{array}$ & $\begin{array}{l}\text { Nominal Ecoliteracy- recognition and use } \\
\text { of some basic terms used in communicating } \\
\text { about the environment, beginning to identify } \\
\text { environmental problems and issues } \\
\text { surrounding proposed solutions; }\end{array}$ \\
\hline 3 & $\begin{array}{l}\text { Hands/active- create and use tools and } \\
\text { procedures required by sustainable } \\
\text { communities, turn convictions into practical } \\
\text { and effective action, assess and adjust uses } \\
\text { of energy and resources; }\end{array}$ & $\begin{array}{l}\text { Functional/operational } \\
\text { understanding of organization and function of } \\
\text { environmental systems and interaction with } \\
\text { human systems, knowledge and skills; }\end{array}$ \\
\hline $\begin{array}{l}\text { Spirit/connectional-experience wonder } \\
\text { and awe toward nature, feel reverence for } \\
\text { the Earth and all living things, feel a strong } \\
\text { bond with and deep appreciation of place, } \\
\text { feel kinship with the natural world and } \\
\text { invoke that feeling in others. }\end{array}$ & $\begin{array}{l}\text { Highly evolved ecoliteracy-thorough } \\
\text { understanding of how people and societies } \\
\text { relate to each other and natural systems, and } \\
\text { how to do so sustainably, thorough } \\
\text { understanding of the environmental crisis, } \\
\text { understanding of models of sustainability, able } \\
\text { to synthesize environmental }\end{array}$ \\
\hline
\end{tabular}

Dalam praktek yang dapat teramati, kecerdasan ekologis dalam merawat lingkungan dapat dilihat melalui kemampuan siswa untuk menjaga lingkungan yang terkait dengan kebersihan (pengelolaan sampah) dan keberadaan tanaman atau pepohonan sebagai pendukung kesehatan lingkungan, contohnya seperti: memastikan sampah berada pada tempatnya, tidak memproduksi sampah berlebih, memperbanyak arena penghijauan (menanam tanaman/pohon), dan merawat tanaman (menyiram, membersihkan, menggemburkan tanah, dan mengamati pertumbuhannya) secara rutin.

Di samping untuk meningkatkan kecerdasan ekologis siswa di kelas dalam merawat lingkungan, penelitian ini ditujukan untuk menjawab beberapa rumusan masalah sebagai berikut: 1) Bagaimana guru mendesain pengembangan topik bencana alam dalam pembelajaran IPS untuk meningkatkan kecerdasan ekologis siswa dalam merawat lingkungan sekolah?; 2) Bagaimana guru menerapkan pengembangan topik bencana alam dalam pembelajaran IPS untuk meningkatkan kecerdasan ekologis siswa dalam merawat lingkungan sekolah?; 3) Bagaimana upaya menghadapi kendala ketika menggulirkan kegiatan menerapkan pengembangan topik bencana alam dalam pembelajaran IPS untuk meningkatkan kecerdasan ekologis siswa dalam merawat lingkungan sekolah?; 4) Bagaimana peningkatan kecerdasan 
ekologis siswa dalam merawat lingkungan sekolah, setelah menerapkan pengembangan topik bencana alam dalam pembelajaran IPS?.

Harapannya penelitian ini dapat memberikan gambaran mengenai salah satu bentuk kegiatan belajar yang dapat diadaptasi oleh para guru untuk meningkatkan kecerdasan ekologis siswa di sekolah.

\section{Metode Penelitian}

Metode yang digunakan dalam penelitian ini adalah metode Penelitian Tindakan Kelas (PTK). Ebbut seperti dikutip oleh Hopkins (Wiriaatmadja, 2009) mengemukakan bahwa "penelitian tindakan adalah kajian sistematik dari upaya perbaikan pelaksanaan praktek pendidikan oleh sekelompok guru dengan melakukan tindakan-tindakan dalam pembelajaran, berdasarkan refleksi mengenai hasil dari tindakan-tindakan tersebut'. Sedangkan menurut Depdiknas (2005), "PTK adalah sebuah penelitian yang dilakukan oleh guru di kelasnya sendiri dengan jalan merancang, melaksanakan, dan merefleksikan tindakan secara kolaboratif dan partisipatif, dengan tujuan untuk memperbaiki kinerjanya sebagai guru sehingga pembelajaran siswa dapat ditingkatkan". Maka dapat disimpulkan bahwa PTK adalah tindakan penelitian yang dilakukan secara kolaboratif oleh guru untuk meningkatkan kualitas pembelajaran di dalam kelas.

Penelitian ini menggunakan model PTK dari Kemmis \& Taggart (diadaptasi dari Wiriaatmadja, 2009) yang terdiri dari empat komponen: Rencana, Tindakan, Pengamatan, dan Refleksi dalam desain spiral multi siklus. Subjek penelitian adalah siswa kelas 7 SMP Semi Palar Bandung yang terdiri dari 13 orang (5 laki-laki dan 8 perempuan). Pemilihan kelas ini berangkat dari pertimbangan peneliti sebagai guru kelas yang dalam kesehariannya mengamati jika kecerdasan ekologis siswa belum terbangun dengan baik.

Dalam penelitian ini, peneliti berperan sebagai guru yang berkolaborasi dengan guru rekan sejawat yang berperan sebagai observer. Selain menjadi observer, rekan sejawat tersebut menjadi partner diskusi dan seorang critical friend yang selalu bersedia memberikan saran positif selama penelitian.

Teknik pengumpulan data dilakukan melalui observasi terbuka dan terstruktur, wawancara, dan studi dokumen (karya dan kegiatan siswa). Kemudian pengolahan data dilakukan dengan menganalisis matriks catatan lapangan, hasil wawancara, dan dokumentasi selama penelitian, untuk merefleksikan pencapaiannnya terdahap tujuan penelitian.

\section{Hasil dan Pembahasan}

Penelitian ini dilaksanakan dalam tujuh kali pertemuan yang dirangkai dalam dua siklus kegiatan. Secara lebih terperinci, pembahasan hasil penelitian dalam setiap siklusnya adalah sebagai berikut:

$\underline{\text { Siklus } 1}$

Pada tahap perencanaan, guru memilih wacana tentang Bencana Kabut Asap di Sumatera dan Kalimantan sebagai topik materi yang akan dikembangkan. Pemilihannya berangkat dari pandangan bahwa topik tersebut selalu menjadi isu besar yang terkait dengan fenomena kerusakan alam di Indonesia. Kegiatan 
direncanakan terdiri dari empat pertemuan yang masing-masingnya fokus pada tahapan kegiatan dari mulai mengorientasikan diri kepada wacana hingga merancang dan melakukan aksi. Dalam proses perencanaan ini, peneliti dan mitra peneliti juga menyiapkan desain Rencana Pelaksaaan Pembelajaran (RPP), instrumen kegiatan untuk metode inkuiri, diskusi, dan praktek lapangan (menanam), serta instrumen untuk observasi.

Pada tahap pelaksanaan, kegiatan di pertemuan pertama dibuka dengan pembagian kelompok dan pemberian pertanyaan esensial: "Bagaimana proses terjadinya bencana kabut asap di Sumatera dan Kalimantan?". Kemudian untuk membantu mencari jawaban, guru memandu kelas untuk merumuskan pertanyaan pengarah tentang bencana kabut asap $(5 \mathrm{~W}+1 \mathrm{H})$ dan mempersilakan setiap kelompok untuk melakukan pencarian informasi melalui media internet dan wawancara di seputar area sekolah. Di pertemuan ke dua, setiap kelompok diminta untuk menyusun permasalahan-permasalahan mengenai bencana kabut asap yang mereka temukan dan membaginya secara lisan di dalam forum kelas untuk menemukan permasalahan utamanya bersama-sama. Dalam diskusi tersebut, kelas menemukan bahwa permasalahan utama dalam bencana kabut asap adalah kerusakan lingkungan akibat berkurangnya jumlah hutan secara drastis sebagai sumber penghasil oksigen di wilayah-wilayah sekitar bencana. Oleh karena itu, di pertemuan ke tiga, siswa merumuskan sebuah solusi untuk ikut memperbaiki kualitas udara dengan membantu menanam dan merawat tanaman sebagai penghasil oksigen. Di pertemuan ke empat, siswa merancang sebuah pot tanaman dari kemasan plastik bekas dan mencoba melakukan pembenihan tanaman dengan media daun pisang. Setelahnya mereka mensortir area sekolah untuk mendata ketersediaan pohon dan membagi peran untuk merawatnya secara berkala.

Pada tahap refleksi, setelah mengolah data-data lapangan, peneliti dan mitra peneliti menyimpulkan bahwa sebaran level kecerdasan ekologis siswa menurut skema MacKenzie adalah sebagai berikut,

Tabel 3

\section{Pencapaian Level Kecerdasan Ekologis Siklus 1}

\begin{tabular}{|l|l|l|}
\hline Level & Keterangan & Jumlah \\
\hline 1 & $\begin{array}{l}\text { Eco-illiteracy: sedikit pemahaman dan banyak kesalahpahaman tentang } \\
\text { isu-isu lingkungan. }\end{array}$ & - \\
\hline 2 & $\begin{array}{l}\text { Nominal Ecoliteracy- pengenalan dan penggunaan beberapa istilah } \\
\text { dasar yang digunakan dalam berkomunikasi tentang lingkungan, mulai } \\
\text { mengidentifikasi permasalahan lingkungan dan isu seputar solusi yang } \\
\text { diusulkan. }\end{array}$ & 8 orang \\
\hline 3 & $\begin{array}{l}\text { Ecoliteracy Fungsional/Operasional - pemahaman tentang organisasi } \\
\text { dan fungsi sistem lingkungan dan interaksi dengan sistem manusia, } \\
\text { pengetahuan dan keterampilan. }\end{array}$ & 7 orang \\
\hline 4 & $\begin{array}{l}\text { Highly evolved ecoliteracy - pemahaman yang menyeluruh tentang } \\
\text { bagaimana orang dan masyarakat saling berhubungan satu sama lain } \\
\text { dan sistem alam, dan bagaimana melakukannya secara berkelanjutan, } \\
\text { pemahaman yang menyeluruh tentang krisis lingkungan, pemahaman } \\
\text { model keberlanjutan, mampu mensintesis lingkungan. }\end{array}$ & - \\
\hline
\end{tabular}


Sedangkan menurut rumusan indikator sasaran, secara umum kecerdasan ekologis siswa mulai tumbuh namun belum merata untuk semua sasaran kemampuan. Berikut penjabaran capaian dilihat dari rata-rata kelasnya.

Tabel 4

Pencapaian Kompetensi Kecerdasan Ekologis Siklus 1

\begin{tabular}{|c|c|c|c|}
\hline Acuan Kompetensi & $\begin{array}{l}\text { Rumusan Indikator } \\
\text { Sasaran }\end{array}$ & Keterangan & Kategori \\
\hline \multirow{4}{*}{$\begin{array}{l}\text { Head (Kognisi) } \\
\text { Mendekati isu dari } \\
\text { perspektif sistem; } \\
\text { memahami prinsip- } \\
\text { prinsip ekologi dasar, } \\
\text { menilai dampak dan } \\
\text { efek etis tindakan } \\
\text { manusia; } \\
\text { membayangkan } \\
\text { konsekuensi jangka } \\
\text { panjang dari } \\
\text { keputusan. }\end{array}$} & $\begin{array}{l}\text { - Siswa dapat } \\
\text { menjelaskan wacana } \\
\text { tentang bencana } \\
\text { kabut asap }\end{array}$ & \multirow{2}{*}{$\begin{array}{l}\text { Dalam catatan hasil } \\
\text { pencarian informasi per } \\
\text { kelompok dan hasil LKS } \\
\text { serta wawancara per } \\
\text { individu, secara umum } \\
\text { semua siswa dapat } \\
\text { menuturkan wacana } \\
\text { kabut asap dengan jelas. }\end{array}$} & \multirow[t]{2}{*}{ Baik } \\
\hline & $\begin{array}{l}\text { - Siswa dapat } \\
\text { memahami penyebab } \\
\text { terjadinya bencana } \\
\text { kabut asap }\end{array}$ & & \\
\hline & $\begin{array}{l}\text { - Siswa dapat } \\
\text { memahami dampak } \\
\text { dari kerusakan } \\
\text { lingkungan terhadap } \\
\text { kelangsungan hidup } \\
\text { masyarakat }\end{array}$ & $\begin{array}{l}\text { Setelah melakukan } \\
\text { kegiatan diskusi, siswa } \\
\text { dapat menjelaskan } \\
\text { dampak kerusakan } \\
\text { lingkungan terhadap } \\
\text { kelangsungan hidup } \\
\text { secara tepat dan jelas. }\end{array}$ & Baik \\
\hline & $\begin{array}{l}\text { - Siswa dapat } \\
\text { menganalisis kondisi } \\
\text { ekologi daerah } \\
\text { bencana kabut asap }\end{array}$ & $\begin{array}{l}\text { Siswa cukup memahami } \\
\text { konsep dasar ekologis } \\
\text { karena juga } \\
\text { mempelajarinya dalam } \\
\text { pelajaran IPA. Namun, } \\
\text { hanya sebagian saja yang } \\
\text { dapat menganalisnya } \\
\text { secara mendalam } \\
\text { (mengidentifikasi ekologi } \\
\text { daerah bencana). }\end{array}$ & Kurang \\
\hline $\begin{array}{l}\text { Heart (Afeksi) } \\
\text { Memberi perhatian, } \\
\text { empati, dan } \\
\text { menghormati orang } \\
\text { lain serta makhluk } \\
\text { hidup }\end{array}$ & $\begin{array}{l}\text { - Siswa dapat } \\
\text { merefleksikan kaitan } \\
\text { antara bencana kabut } \\
\text { asap dengan kondisi } \\
\text { diri dan } \\
\text { lingkungannya }\end{array}$ & $\begin{array}{l}\text { Dalam catatan refleksi } \\
\text { yang dibuat siswa, } \\
\text { mengindikasikan bahwa } \\
\text { mereka dapat mengaitkan } \\
\text { bencana kabut asap } \\
\text { dengan kondisi diri dan } \\
\text { lingkungannya. }\end{array}$ & Cukup \\
\hline \multirow[t]{2}{*}{$\begin{array}{l}\text { Hands (Psikomotor) } \\
\text { Mengubah keyakinan } \\
\text { ke dalam tindakan } \\
\text { yang praktis dan } \\
\text { efektif. }\end{array}$} & $\begin{array}{l}\text { - Siswa dapat } \\
\text { melakukan } \\
\text { pembenihan dan } \\
\text { penyemaian tanaman } \\
\text { dengan prosedur } \\
\text { yang tepat. }\end{array}$ & $\begin{array}{l}\text { Pembenihan dan } \\
\text { penyemaian dilakukan } \\
\text { secara bersama-sama. } \\
\text { Oleh karenanya, beberapa } \\
\text { siswa yang kurang } \\
\text { terampil mengolah dapat } \\
\text { terbantu oleh temannya } \\
\text { yang lain. }\end{array}$ & Cukup \\
\hline & $\begin{array}{l}\text { - Siswa dapat merawat } \\
\text { tanaman dengan } \\
\text { menyiram dan }\end{array}$ & $\begin{array}{l}\text { Pada awalnya semua } \\
\text { siswa melakukan } \\
\text { perawatan tanaman }\end{array}$ & Kurang \\
\hline
\end{tabular}




\begin{tabular}{|c|c|c|c|}
\hline & $\begin{array}{l}\text { membersihkan } \\
\text { tanaman secara } \\
\text { berkala. }\end{array}$ & $\begin{array}{l}\text { dengan baik. Namun, } \\
\text { beberapa hari berselang } \\
\text { teramati mereka belum } \\
\text { dapat melakukannya } \\
\text { secara konsisten. }\end{array}$ & \\
\hline $\begin{array}{l}\text { Spirit (Nurani) } \\
\text { Merasakan ikatan } \\
\text { yang kuat dengan } \\
\text { apresiasi yang } \\
\text { mendalam terhadap } \\
\text { lingkungan tempat } \\
\text { tinggal. }\end{array}$ & $\begin{array}{l}\text { - Siswa dapat } \\
\text { berperilaku positif } \\
\text { terhadap lingkungan } \\
\text { sekitar sekolah } \\
\text { dengan memastikan } \\
\text { tidak ada sampah } \\
\text { berserakan dan tidak } \\
\text { ada tanaman/pohon } \\
\text { yang tidak terawat. }\end{array}$ & $\begin{array}{l}\text { Dari catatan refleksi dan } \\
\text { perilaku keseharian, } \\
\text { secara umum siswa sudah } \\
\text { tergerak untuk } \\
\text { memperhatikan } \\
\text { kebersihan lingkungan } \\
\text { dari sampah, namun } \\
\text { konsistensi } \\
\text { memperhatikan } \\
\text { perawatan tanaman masih } \\
\text { perlu terus dibangun agar } \\
\text { dapat optimal. }\end{array}$ & Kurang \\
\hline
\end{tabular}

Selama melaksanakan rangkaian tindakan di siklus pertama, peneliti menemukan kendala utama yakni kesulitan untuk membuat keterhubungan yang bermakna antara topik materi kegiatan dengan kondisi kehidupan keseharia siswa. Peneliti dan mitra peneliti berkesimpulan bahwa masih belum memuaskannya pencapaian kesadaran ekologis siswa bukan hanya diakibatkan oleh faktor siswa, namun oleh faktor guru yang memilih topik bencana terlalu berjarak dari realitas kehidupan siswa seharihari. Akhirnya sebagai tindakan perbaikan, guru harus memilih topik bencana yang dekat dengan lingkungan kehidupan siswa untuk kegiatan belajar di siklus selanjutnya.

\section{Siklus 2}

Pada tahap perencanaan, guru memilih wacana tentang Bencana Banjir Bandang di Garut sebagai topik materi yang akan dikembangkan. Pemilihannya berangkat dari pandangan bahwa topik tersebut lebih dekat dengan lingkungan kehidupan siswa dan secara kebetulan belum lama terjadi sehingga siswa dapat membangun empati kepada korban terdampak bencana yang masih memerlukan bantuan karena masih berada di tempat pengungsian. Kegiatan direncanakan terdiri dari tiga pertemuan yang masing-masingnya fokus pada tahapan kegiatan sesuai dengan alur kegiatan yang sudah dilakukan pada siklus yang pertama. Desain Rencana Pelaksaaan Pembelajaran (RPP), instrumen kegiatan untuk meotde inkuiri, diskusi, dan praktek lapangan (menanam), serta instrumen observasi sudah disiapkan bersama oleh peneliti dan mitra peneliti dalam proses perencanaan ini.

Pada tahap pelaksanaan, kegiatan di pertemuan pertama dibuka dengan pemberian artikel feature mengenai berita banjir Garut dari sudut pandang korban. Siswa diminta untuk membaca dengan serius artikel tersebut secara individu. Dari kegiatan tersebut, empati siswa mulai terbangun dengan munculnya reaksi-reaksi keprihatinan dan keinginan untuk membantu. Setelahnya guru membagi kelompok dan melemparkan pertanyaan esensial: "Bagaimana proses terjadinya bencana banjir bandang di Garut dan apa kaitannya dengan kita?". Kemudian untuk membantu mencari jawaban, guru kembali memandu kelas untuk merumuskan pertanyaan pengarah tentang bencana banjir Garut $(5 \mathrm{~W}+1 \mathrm{H})$ dan mempersilakan setiap 
kelompok untuk melakukan pencarian informasi (dalam bentuk berita dan video reportase) melalui media internet. Di pertemuan ke dua, setiap kelompok diminta untuk menyusun permasalahan-permasalahan mengenai bencana banjir Garut yang mereka temukan dan membaginya secara lisan kepada forum kelas untuk menemukan permasalahan utamanya. Dalam diskusi tersebut, kelas menemukan bahwa permasalahan utama dalam bencana banjir Garut adalah kerusakan lingkungan akibat berkurangnya jumlah hutan di daerah hulu sungai sebagai daerah resapan air penahan banjir di wilayah-wilayah sekitar bencana. Menyadari bahwa daerah Bandung tempat mereka tinggal juga memiliki potensi bencana yang serupa, oleh karena itu di pertemuan ke tiga, di samping kegiatan menyemai benih yang sudah ditanam pada siklus ke-1, siswa merumuskan sebuah solusi untuk ikut menjaga kelestarian lingkungan dengan mengawasi sampah dan menjaga serta merawat tanaman untuk ikut memastikan ketersediaan daerah resapan air di lingkungan sekolah.

Pada tahap refleksi, setelah mengolah data-data lapangan, peneliti dan mitra peneliti menyimpulkan bahwa sebaran level kecerdasan ekologis siswa menurut skema MacKenzie mengalami peningkatan sebagai berikut,

Tabel 5

Pencapaian Level Kecerdasan Ekologis Siklus 2

\begin{tabular}{|l|l|l|}
\hline Level & Keterangan & Jumlah \\
\hline 1 & $\begin{array}{l}\text { Eco-illiteracy: sedikit pemahaman dan banyak kesalahpahaman tentang } \\
\text { isu-isu lingkungan. }\end{array}$ & - \\
\hline 2 & $\begin{array}{l}\text { Nominal Ecoliteracy- pengenalan dan penggunaan beberapa istilah } \\
\text { dasar yang digunakan dalam berkomunikasi tentang lingkungan, mulai } \\
\text { mengidentifikasi permasalahan lingkungan dan isu seputar solusi yang } \\
\text { diusulkan. }\end{array}$ & - \\
\hline 3 & $\begin{array}{l}\text { Ecoliteracy Fungsional/Operasional - pemahaman tentang organisasi } \\
\text { dan fungsi sistem lingkungan dan interaksi dengan sistem manusia, } \\
\text { pengetahuan dan keterampilan. }\end{array}$ & $\begin{array}{l}11 \\
\text { orang }\end{array}$ \\
\hline 4 & $\begin{array}{l}\text { Highly evolved ecoliteracy - pemahaman yang menyeluruh tentang } \\
\text { bagaimana orang dan masyarakat saling berhubungan satu sama lain } \\
\text { dan sistem alam, dan bagaimana melakukannya secara berkelanjutan, } \\
\text { pemahaman yang menyeluruh tentang krisis lingkungan, pemahaman } \\
\text { model keberlanjutan, mampu mensintesis lingkungan. }\end{array}$ & 2 orang \\
\hline
\end{tabular}

Sedangkan menurut rumusan indikator sasaran, secara umum kecerdasan ekologis siswa sudah tumbuh dan bisa dinilai merata dan mencukupi untuk semua sasaran kemampuan. Berikut penjabaran capaian dilihat dari rata-rata kelasnya.

Tabel 6

Pencapaian Kompetensi Kecerdasan Ekologis Siklus 2

\begin{tabular}{|c|c|c|c|}
\hline $\begin{array}{l}\text { Acuan } \\
\text { Kompetensi }\end{array}$ & $\begin{array}{l}\text { Rumusan Indikator } \\
\text { Sasaran }\end{array}$ & Keterangan & Kategori \\
\hline $\begin{array}{l}\text { Head (Kognisi) } \\
\text { Mendekati isu } \\
\text { dari perspektif } \\
\text { sistem; }\end{array}$ & $\begin{array}{l}\text { - Siswa dapat } \\
\text { menjelaskan wacana } \\
\text { tentang bencana } \\
\text { banjir Garut }\end{array}$ & $\begin{array}{l}\text { Dalam catatan hasil pencarian } \\
\text { informasi per kelompok dan } \\
\text { hasil LKS serta wawancara } \\
\text { per individu, secara umum }\end{array}$ & Baik \\
\hline
\end{tabular}




\begin{tabular}{|c|c|c|c|}
\hline \multirow{3}{*}{$\begin{array}{l}\text { memahami } \\
\text { prinsip-prinsip } \\
\text { ekologi dasar, } \\
\text { menilai dampak } \\
\text { dan efek etis } \\
\text { tindakan manusia; } \\
\text { membayangkan } \\
\text { konsekuensi } \\
\text { jangka panjang } \\
\text { dari keputusan. }\end{array}$} & $\begin{array}{l}\text { - Siswa dapat } \\
\text { memahami penyebab } \\
\text { terjadinya bencana } \\
\text { banjir Garut }\end{array}$ & $\begin{array}{l}\text { semua siswa dapat } \\
\text { menuturkan wacana banjir } \\
\text { Garut dengan jelas dan rinci. }\end{array}$ & \\
\hline & $\begin{array}{l}\text { - Siswa dapat } \\
\text { memahami dampak } \\
\text { dari kerusakan } \\
\text { lingkungan terhadap } \\
\text { kelangsungan hidup } \\
\text { masyarakat }\end{array}$ & $\begin{array}{l}\text { Setelah melakukan kegiatan } \\
\text { diskusi, siswa dapat } \\
\text { menjelaskan dampak } \\
\text { kerusakan lingkungan } \\
\text { terhadap kelangsungan hidup } \\
\text { secara tepat dan jelas. }\end{array}$ & Baik \\
\hline & $\begin{array}{l}\text { - Siswa dapat } \\
\text { menganalisis kondisi } \\
\text { ekologi daerah } \\
\text { bencana banjir Garut }\end{array}$ & $\begin{array}{l}\text { Pemahaman ekologi yang } \\
\text { semakin bertambah, } \\
\text { ketersediaan sumber informasi } \\
\text { yang kaya, kejelasan penyebab } \\
\text { bencana, dan kedekatan lokasi } \\
\text { bencana dengan lingkungan } \\
\text { siswa membuat siswa dapat } \\
\text { menguraikan kondisi ekologi } \\
\text { daerah bencana dengan jelas } \\
\text { dan rinci. }\end{array}$ & Baik \\
\hline $\begin{array}{l}\text { Heart (Afeksi) } \\
\text { Memberi } \\
\text { perhatian, empati, } \\
\text { dan menghormati } \\
\text { orang lain serta } \\
\text { makhluk hidup }\end{array}$ & $\begin{array}{l}\text { - Siswa dapat } \\
\text { merefleksikan kaitan } \\
\text { antara bencana } \\
\text { banjir Garut dengan } \\
\text { kondisi diri dan } \\
\text { lingkungannya }\end{array}$ & $\begin{array}{l}\text { Dalam catatan refleksi yang } \\
\text { dibuat siswa, mengindikasikan } \\
\text { bahwa mereka dapat } \\
\text { mengaitkan bencana kabut } \\
\text { asap dengan kondisi diri dan } \\
\text { lingkungannya. }\end{array}$ & Cukup \\
\hline \multirow[t]{2}{*}{$\begin{array}{l}\text { Hands } \\
\text { (Psikomotor) } \\
\text { Mengubah } \\
\text { keyakinan ke } \\
\text { dalam tindakan } \\
\text { yang praktis dan } \\
\text { efektif. }\end{array}$} & $\begin{array}{l}\text { - Siswa dapat } \\
\text { melakukan } \\
\text { pembenihan dan } \\
\text { penyemaian tanaman } \\
\text { dengan prosedur } \\
\text { yang tepat. }\end{array}$ & $\begin{array}{l}\text { Di siklus ke dua, tahap } \\
\text { kegiatan ini dilanjutkan } \\
\text { dengan memindahkan bibit ke } \\
\text { dalam wadah yang sudah } \\
\text { disiapkan. Dalam prosesnya, } \\
\text { kegiatannya berjalan baik dan } \\
\text { lancar. }\end{array}$ & Baik \\
\hline & $\begin{array}{l}\text { - Siswa dapat merawat } \\
\text { tanaman dengan } \\
\text { menyiram dan } \\
\text { membersihkan } \\
\text { tanaman secara } \\
\text { berkala. }\end{array}$ & $\begin{array}{l}\text { Setelah melaksanakan } \\
\text { kegiatan di siklus ke dua, } \\
\text { gairah siswa untuk merawat } \\
\text { tanaman semakin tergenapi. } \\
\text { Sejauh yang peneliti amati, } \\
\text { sebagian besar siswa sudah } \\
\text { mulai konsisten untuk } \\
\text { merawat tanaman dalam } \\
\text { kesehariannya. }\end{array}$ & Cukup \\
\hline $\begin{array}{l}\text { Spirit (Nurani) } \\
\text { Merasakan ikatan } \\
\text { yang kuat dengan } \\
\text { apresiasi yang } \\
\text { mendalam } \\
\text { terhadap } \\
\text { lingkungan } \\
\text { tempat tinggal. }\end{array}$ & $\begin{array}{l}\text { - Siswa dapat } \\
\text { berperilaku positif } \\
\text { terhadap lingkungan } \\
\text { sekitar sekolah } \\
\text { dengan memastikan } \\
\text { tidak ada sampah } \\
\text { berserakan dan tidak } \\
\text { ada tanaman/pohon } \\
\end{array}$ & $\begin{array}{l}\text { Dari catatan refleksi dan } \\
\text { perilaku keseharian, secara } \\
\text { umum siswa sudah tergerak } \\
\text { untuk memperhatikan } \\
\text { kebersihan lingkungan dari } \\
\text { sampah. Di samping itu, } \\
\text { konsistensi memperhatikan } \\
\text { perawatan tanaman juga sudah }\end{array}$ & Cukup \\
\hline
\end{tabular}




\begin{tabular}{|l|l|l|l|}
\hline & yang tidak terawat. & $\begin{array}{l}\text { mulai terbangun pada } \\
\text { sebagian besar siswa }\end{array}$ & \\
\hline
\end{tabular}

Selama melaksanakan rangkaian tindakan di siklus ke dua, peneliti tidak menemukan kendala yang cukup berarti sebagai penghambat efektifitas kegiatan belajar. Peneliti akhirnya menyimpulkan jika topik Bencana Banjir Garut yang secara ruang dan waktu peristiwa tidak terlalu jauh dari kehidupan siswa, dapat menjadi topik jitu yang telah menggenapkan peningkatan kecerdasan ekologis dalam diri siswa. Mengingat sasaran untuk meningkatkan kesadaran ekologis dalam merawat lingkungan sudah tercapai, dan kegiatan dikhawatirkan akan mengalami kejenuhan karena sudah mencapai 7 pertemuan, maka peneliti dan mitra peneliti memutuskan untuk mengakhiri siklus penelitian.

\section{Kesimpulan}

Berdasarkan olahan pembahasan hasil penelitian, dapat disimpulkan bahwa pengembangan topik bencana dalam pembelajaran IPS dengan metode belajar aktif dapat meningkatkan kecerdasan ekologis siswa secara efektif di kelas 7 SMP Semi Palar Bandung. Namun, karena kecerdasan ekologis berada pada ranah kognisi, afeksi, dan psikomotor, peningkatan dalam ranah afeksi-psikomotor dalam bentuk konsistensi merawat tanaman perlu terus dijaga rutinitasnya secara berkala dalam waktu yang terus menerus agar dapat mengarakter dalam diri siswa.

Dalam proses penelitian ini, beberapa hal yang menjadi catatan peneliti sebagai saran hasil penelitian adalah; Pertama, selama melakukan penelitian ini, kondisi kelas yang sudah memiliki kemampuan belajar aktif cenderung memudahkan guru untuk melakukan setiap tindakan perbaikan dalam pembelajaran. Oleh karena itu, perlu sekali untuk membangun kemampuan siswa agar dapat belajar aktif dalam setiap kegiatan belajar, karena dengan kemampuan tersebut siswa akan lebih siap untuk diajak terlibat dalam pengembangan beragam metode pembelajaran untuk mencapai sasaran pembelajaran yang diharapkan. Ke dua, topik bencana Banjir Bandang di Garut yang secara ruang berdekatan dengan siswa terasa lebih powerful dalam membangun koneksi antara siswa dengan apa yang sedang mereka pelajari dibandingkan dengan topik Bencana Kabut Asap di Sumetara dan Kalimantan. Oleh karena itu, guru harus dapat selalu memilih topik materi yang paling dekat dengan kehidupan siswa agar membuat pembelajaran dapat semakin terasa bermakna bagi mereka. Ke tiga, mengembangkan pendekatan ekopedagogi dengan metode belajar aktif dan topik lingkungan yang bermakna dapat menjadi cara bagi guru untuk meningkatkan kecerdasan ekologis siswa. Oleh karena itu, sangat dimungkinkan bagi guru untuk dapat mengembangkan beragam metode dan topik belajar menurut kebutuhan dan kondisi kelasnya sendiri, bahkan untuk mencapai sasaran kesadaran ekologis yang lebih lengkap dan kompleks di jenjang berikutnya.

\section{Daftar Pustaka}

Antunes, A. \& Gadotti, M. (2011). Eco-pedagogy as the apprpriate pedagogy to the earth charter process. [Online]. Tersedia: http://www.earthcharterinaction.org/pdfs/TEC-ENG-PDF/ENG-Antunes.pdf [1

Oktober 2016]. 
Blake, Caitrin. (2015). Earth Literacy: Defining a Crucial Curriculum for Students. [Online]. Tersedia: http://online.cune.edu/defining-earth-literacy/ [1 Oktober 2016]

FWI/GFW. (2001). Keadaan Hutan Indonesia. Bogor: Forest Watch Indonesia dan Washington D.C.: Global Forest Watch.

McBride, B. B., C. A. Brewer, A. R. Berkowitz, and W. T. Borrie. (2013).

Environmental Literacy, Ecological Literacy, Ecoliteracy: What Do We Mean and How Did We Get Here?. Ecosphere Journal 4 (5):67. http://dx.doi.org/10.1890/ES1300075.1

Orr, David W. (2009). The Intelligence of Ecological Design. [Online]. Tersedia: https://www.ecoliteracy.org/article/intelligence-ecological-design [1 Oktober 2016].

Pranadji, Tri. (2005). Keserakahan, Kemiskinan, dan Kerusakan Lingkungan . (Makalah). Disampaikan dalam Seminar Nasional V Ikatan Sosiologi Indonesia, 20 September 2005 di Gedung Pertemuan BKKBN Jakarta.

Putra, Nusa. (2013). Penelitian Kualitatif IPS. Bandung: PT Remaja Rosdakarya.

Sabo, Helena Maria. (2012). Environmental Education and Eco-pedagogy. [Online]. Tersedia: http://educatia21.reviste.ubbcluj.ro/index_htm_files/Sabo_2_10_2012.pdf [1 Oktober 2016].

Stone, Michael K. \& Barlow, Zenobia. (2009). Smart by Nature: Schooling for Sustainability. [Online]. Tersedia:

https://www.ecoliteracy.org/sites/default/files/ecoliteracy-post-carbonreader2010.pdf [1 Oktober 2016].

Supriatna, Nana. (2016). Ecopedagogy: Membangun Kecerdasan Ekologis dalam Pembelajaran IPS. Bandung: PT Remaja Rosdakarya.

WALHI. (2014). Tinjauan Lingkungan Hidup WALHI 2014. [Online]. Tersedia; http://www.walhi.or.id/wp-content/uploads/2014/01/ENV-OUTLOOK-2014FINAL.pdf [1 Oktober 2016]

Wiriaatmadja, Rochiati. (2009). Metode Penelitian Tindakan Kelas. Bandung: PT Remaja Rosdakarya. 